\title{
Theoretical approach model of building integrated photovoltaic thermal air collector
}

\author{
Ahmad Fudholi ${ }^{1}$, Muhammad Zohri ${ }^{2}$, Ivan Taslim ${ }^{3}$, Merita Ayu Indrianti ${ }^{4}$, Intan Noviantari Manyoe ${ }^{5}$ \\ ${ }^{1,2}$ Solar Energy Research Institute, Universiti Kebangsaan Malaysia, Malaysia \\ ${ }^{3,4}$ Universitas Muhammadiyah Gorontalo, Gorontalo, Indonesia \\ ${ }^{5}$ Universitas Negeri Gorontalo, Gorontalo, Indonesia
}

\begin{tabular}{l}
\hline \hline Article Info \\
\hline Article history: \\
Received Mar 1, 2019 \\
Revised Nov 8, 2019 \\
Accepted Jan 23, 2020 \\
\hline
\end{tabular}

Keywords:

Heat transfer

Renewable energy

Solar collector

Thermal modelling

\begin{abstract}
Over recent years the photovoltaic technology has obtained significant development, especially in building integrated photovoltaic thermal (BIPVT) system. Photovoltaic thermal (PVT) air collectors are advantageous because of their efficiency. Various studies have been conducted to determine the ideal parameters of PVT air collectors. Few theoretical approach models of PVT air collector systems were used to help detect occurrences in a PVT collector system and calculate the optimal parameters. The heat transfer and energy balance of PVT air collectors were analysed and reviewed based on the model, quantity of cover, channels and forms of the collector. A mathematical model was developed to describe actual working situations and to examine new shut PVT collectors. The first law of thermodynamics is the principal equation in the model. Different analysis methods were utilised to evaluate PVT performances, which are generally based on energy and exergy analyses. This review focuses on theoretical approach model of single-pass PVT air collector.
\end{abstract}

This is an open access article under the $\underline{C C B Y-S A}$ license.

\section{Corresponding Author:}

Ivan Taslim,

Universitas Muhammadiyah Gorontalo,

Jl. Prof. Dr. H. Mansoer Pateda No. Desa, Pentadio Tim., Gorontalo 96181, Indonesia.

Email: ivantaslim@umgo.ac.id

\section{INTRODUCTION}

The depletion of conventional fossil fuel resources has revived the demand for utilisation of renewable energy resources. Therefore, an alternative energy source must be determined to satisfy our energy requirements and preserve conventional fossil fuels. One such renewable energy source is solar energy, which can potentially supply significant amount of the world's energy demand. Renewable energy sources, such as solar energy, provide environmental benefits and clean energy. In addition, solar energy is an ideal alternative source for impoverished or rural people who have no access to modern energy sources. Thermal and electrical energy can be generated from solar energy. Although these two energy sources are have different forms, they can be produced simultaneously by using hybrid collectors. This hybrid system consists of a combination of two types of collectors, namely, thermal collectors and photovoltaic-thermal (PVT) collectors. PVT collectors are designed to receive solar energy and convert it into thermal and electrical energy; in this device, thermal energy is transferred into fluid that flows into the collector. A PVT collector consists of a PV panel, an insulator and a frame as well as one or more cover (glass sheets) or a transparent material placed over the absorbing plate with air flowing around it. The efficiency of PVT collectors can be enhanced by using heat transfer area through the absorber with finned absorbers, corrugated surfaces and 
porous media. PVT collectors can be classified into four types according to the heat transfer medium: airbased, water-based, combined water/air-based and nanofluid-based PVT collectors [1-13].

The overall performance of the PVT system can be evaluated based on the thermodynamic, environmental and economic impacts analysis. Enviroeconomic and exergoeconomic analyses for PVT air collectors were studied [14]. Environmental-economic-exergy-energy analyses for different PVT air collector systems were studied [15-17]. Several types of PVT air collectors have been designed, evaluated and developed in various countries, thereby yielding varying degrees of technical performances based on energy-exergy analyses. In this review, we focused on the theoretical approach model of singlepass PVT air collector.

\section{THEORETICAL APPROACH MODEL OF PVT AIR COLLECTORS WITHOUT GLASS COVER}

Sarhaddi et al. $[18,19]$ improved the thermal and electrical model for a PVT air collector, as shown in Figure 1. The figure shows the cross-sectional view of the PVT air collector, as well as its equivalent thermal resistant circuit and an element length ' $\mathrm{dx}$ ' of the flow channel. The energy balance of the PVT collector is expressed as follows.

For the PV module:

$$
\begin{aligned}
& \tau_{g}\left[\alpha_{p v} I \beta_{p v}+\left(1-\beta_{p v}\right) \alpha_{T} I\right] b d x= \\
& {\left[h_{p v a}\left(T_{p v}-T_{a}\right)+h_{p v T}\left(T_{p v}-T_{T}\right)\right] b d x+\eta_{p v} I \beta_{p v} b d x}
\end{aligned}
$$

For the back surface of a Tedlar:

$$
h_{p v T}\left(T_{p v}-T_{T}\right) b d x=h_{T f}\left(T_{T}-T_{f}\right) b d x
$$

For the air flowing below a Tedlar:

$$
h_{T f}\left(T_{T}-T_{f}\right) b d x=\dot{m} C \frac{d T}{d x} d x+U_{b}\left(T_{f}-T_{a}\right) b d x
$$

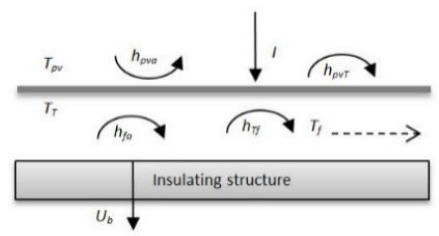

Figure 1. Schematic of temperatures and heat transfer coefficients of a PVT air collector

In the application of PVT system, Sahsavar et al. [20] developed a building integrated photovoltaic (BIPVT) collector by using the cooling potential of ventilation and exhaust air to refrigerate the PV panel and heating system in the ventilation of buildings. The energy balance of this PVT collector, as shown in Figure 2, is expressed as follows.

For PV panels:

$$
\begin{aligned}
& \alpha_{p v}\left(1-\eta_{e l}\right) I A d x= \\
& \left(h_{w}+h_{r, p v s}\right)\left(T_{p v}-T_{a}\right) A d x+h_{p v f}\left(T_{p v}-T_{f}\right) A d x+h_{r, p v b}\left(T_{p v}-T_{b}\right) A d x
\end{aligned}
$$

For the air channel:

$$
\dot{m}_{f} C_{p} d T_{f}=h_{p v f}\left(T_{p v}-T_{f}\right) A d x+h_{b f}\left(T_{b}-T_{f}\right) A d x
$$

For the bottom plate:

$$
h_{r p v b}\left(T_{p v}-T_{b}\right) A d x=U_{b}\left(T_{b}-T_{a}\right) A d x+h_{b f}\left(T_{b}-T_{f}\right) A d x
$$




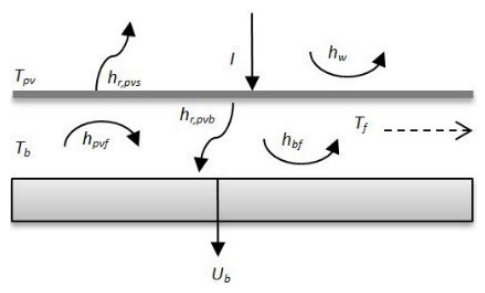

Figure 2. Schematic of heat transfer coefficients and temperatures of a PVT air collector

Sohel et al. [21] proposed a dynamic model for PVT air collectors, as shown in Figure 3. The experimental data were similar with the modelled air temperature and electrical performance. The data from the PVT system were used to authenticate the theoretical approach in two buildings. The system energy balance for the heat loss from the top of the PVT is expressed as follows:

$$
Q_{p v}=A h_{p v a}\left(T_{p v}-T_{a}\right)+A h_{r, p v s}\left(T_{p v}-T_{s}\right) .
$$

From the PV panel to the air in the channel:

$$
Q_{p v f}=A h_{p v f}\left(T_{p v}-T_{f}\right)
$$

From the PV panel to the roof top:

$$
Q_{p v r}=A h_{r, p v r}\left(T_{p v}-T_{r}\right)
$$

The system energy balance for the heat loss from air to the roof and from roof to the room is determined as

$$
\begin{aligned}
& Q_{f r}=A h_{f r}\left(T_{f}-T_{r}\right), \\
& Q_{r r m}=A U_{r r m}\left(T_{r}-T_{r m}\right)
\end{aligned}
$$

The energy balance of the air strip can be calculated as

$$
\dot{m}_{f} C_{p v f} \frac{d T_{f}}{d x}=A h_{p v f}\left(T_{p v}-T_{f}\right)-A h_{f r}\left(T_{f}-T_{r}\right)
$$

The energy balance around an infinitesimal control volume of the PV panel can be calculated as

$$
\begin{aligned}
& m_{p v} C_{p v} \frac{d T_{p}}{d t}=(1-\rho) \cdot I A M \cdot\left(1-\eta_{p v}\right) d A . I-A h_{p v a}\left(T_{p v}-T_{a}\right)- \\
& A h_{r, p v s}\left(T_{p v}-T_{s}\right)-A h_{p v a}\left(T_{p v}-T_{a}\right)-A h_{r, p v r}\left(T_{p v}-T_{r}\right) . \\
& \hline T_{r m}
\end{aligned}
$$

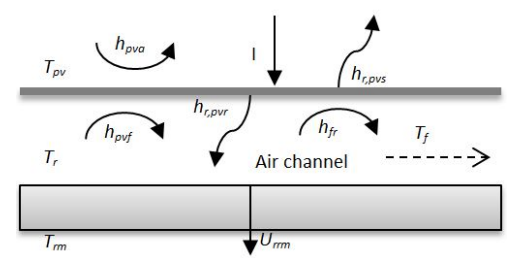

Figure 3. Schematic of heat transfer coefficients and temperatures of a PVT air collector

Vats et al. [22] analysed the energy and exergy performances of a semi-transparent BIPVT system using an integrated PV panel, as shown in Figure 4. The energy balance of this PVT collector is expressed as follows. For the semi-transparent PV module:

Int J Pow Elec \& Dri Syst, Vol. 11, No. 2, June 2020 : $1002-1010$ 


$$
\tau_{g} \alpha_{p v} \beta_{p v} I A d x=h_{p v a}\left(T_{p v}-T_{a}\right) A d x+h_{p v r}\left(T_{p v}-T_{r}\right) A d x+\eta_{p v} I A d x
$$

For the room air temperature:

$$
\begin{aligned}
& h_{p v, r}\left(T_{p v}-T_{r}\right) A_{p v}+\tau_{g}^{2}\left(1-\beta_{p v}\right) I A_{p v}= \\
& M C \frac{d T_{r}}{d t}+U_{r}\left(T_{r}-T_{a}\right)+0.33 N V\left(T_{r}-T_{a}\right)
\end{aligned}
$$

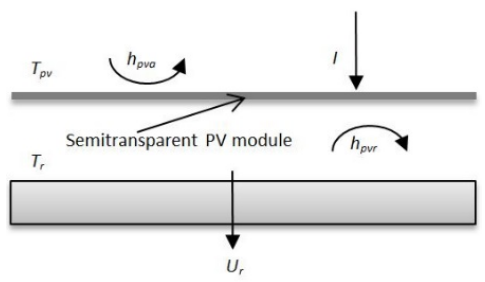

Figure 4. Schematic of heat transfer coefficients and temperatures of a PVT air collector

Yang et al. [23] examined the thermal features of an innovative two-inlet, open-loop BIPVT air collector, as shown in Figure 5. The thermal efficiency of the two-inlet systems was 5\% higher than that of a conventional one-inlet system. The thermal efficiency of the BIPVT system with a semi-transparent PV panel reached approximately $7.6 \%$. This system can be easily applied and does not significantly increase cost. The energy balance of this PVT collector is expressed as follows.

For the top PV panel surface:

$$
I_{p v}=\frac{A \sigma\left(T_{p v}^{4}-T_{i n s}^{4}\right)}{\frac{1}{\varepsilon_{p v}}+\frac{1}{\varepsilon_{i n s}}-1}+A h_{p v a}\left(T_{p v}-T_{a}\right)+A h_{p v f}\left(T_{p v}-T_{f}\right)
$$

For the fluid in the BIPVT:

$$
\dot{m} C_{p}\left(T_{o}-T_{i}\right)=A h_{p v f}\left(T_{p v}-T_{a}\right)+A h_{b o t}\left(T_{i n s}-T_{f}\right)
$$

For the lining inner surface:

$$
I_{i n s}+\frac{A \sigma\left(T_{p v}^{4}-T_{i n s}^{4}\right)}{\frac{1}{\varepsilon_{p v}}+\frac{1}{\varepsilon_{i n s}}-1}=A h_{b o t}\left(T_{i n s}-T_{f}\right)
$$

For the PV panel bottom surface:

$$
I_{p v}=G A F \alpha_{p v}+G A(1-F) \alpha_{g}+G A(1-F) \tau_{g} \rho_{i n s} \alpha_{p v}-E
$$

For the solar radiation incident in the insulation:

$$
I_{\text {ins }}=G A(1-F) \alpha_{i n s} \tau_{g}
$$

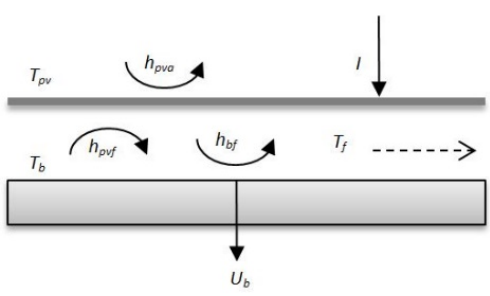

Figure 5. Schematic of temperatures and heat transfer coefficients of a PVT air collector 


\section{THEORETICAL APPROACH MODEL OF PVT AIR COLLECTORS WITH GLASS COVER}

Aste et al. [24] investigated a PVT air collector. A simulation model was developed to calculate the performance of the system. The simulated and experimental thermal and electrical performances of the PVT collector were consistent. The system has been applied to solar rooftops and buildings. The energy balance of this PVT air collector, as shown in Figure 6, is expressed as follows.

For PV cells:

$$
\begin{aligned}
& I A_{p v} \tau_{g} \alpha_{p v}\left(1-\frac{\eta^{*}}{\tau_{g} \alpha_{p v}}\right)= \\
& A_{p v} h_{p v a}\left(T_{p v}-T_{a}\right)+A_{p v} h_{p v f}\left(T_{p v}-T_{f}\right)+A_{p v} h_{r, p v p}\left(T_{p v}-T_{p}\right)
\end{aligned}
$$

For the glass part of the sandwich without PV cells inside:

$$
I A_{g} \alpha_{g}=A_{g} h_{g a}\left(T_{g}-T_{a}\right)+A_{g} h_{g f}\left(T_{g}-T_{f}\right)+A_{g} h_{r, g p}\left(T_{g}-T_{p}\right)
$$

For the air gap:

$$
M_{f} C\left(T_{o}-T_{i}\right)=A_{p v} h_{p v f}\left(T_{p v}-T_{f}\right)+A_{g} h_{g f}\left(T_{g}-T_{f}\right)+A_{p} h_{p f}\left(T_{p}-T_{f}\right)
$$

For the absorber plate:

$$
\begin{aligned}
& I A_{g} \tau_{g} \alpha_{p}+A_{p v} h_{r, p v p}\left(T_{p v}-T_{p}\right)+A_{g} h_{r, g p}\left(T_{g}-T_{p}\right)= \\
& A_{p} h_{p f}\left(T_{p}-T_{f}\right)+U_{b} A_{p}\left(T_{p}-T_{b}\right)
\end{aligned}
$$

For the PV, the actual thermal-spectral efficiency is

$$
\eta^{*}=\eta_{n} \frac{100-\gamma\left(T_{p v}-25\right)}{100 F S}
$$

where $\gamma$ is the temperature power coefficient of $\mathrm{PV}$ cells, and FS is the spectrum correction factor of $\mathrm{PV}$ efficiency.

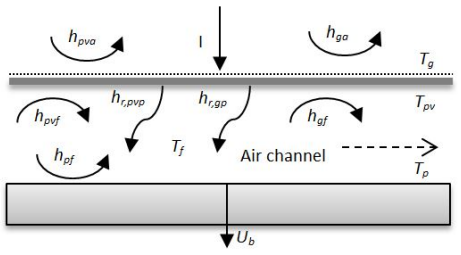

Figure 6. Heat transfer coefficients and temperatures of a PVT air collector

Another heat transfer and energy modelling for PVT air collectors with glass cover were proposed in [25-27]. The analytical expression for the electrical efficiency of PVT hybrid air collectors was established. Case A is a glass-to-glass PV module with an air channel above the absorber plate, and Case B is a glass-to-glass PV module with air channel below the absorber plate. The energy balance of this PVT air collector, as shown in Figure 7, is expressed as follows:

Case A: Glass-to-glass PV module with an air channel above the absorber plate For the PV module:

$$
\begin{aligned}
& \alpha_{p v} \tau_{g} \beta_{p v} S(t) b d x= \\
& {\left[U_{t, p v}\left(T_{p v}-T_{a}\right)+U_{p v, f}\left(T_{p v}-T_{f}\right) b d x\right]+\tau_{g} \eta \alpha_{p v} \beta_{p v} S(t) b d x}
\end{aligned}
$$

For the blackened absorber plate:

Int J Pow Elec \& Dri Syst, Vol. 11, No. 2, June 2020 : $1002-1010$ 


$$
\left[\alpha_{p}\left(1-\beta_{p v}\right) \tau_{g}^{2} I(t)\right] b d x=\left[h_{p f}\left(T_{p}-T_{f}\right)+U_{p a}\left(T_{p}-T_{a}\right)\right] b d x
$$

For air flowing through the channel:

$$
\dot{m}_{a} C_{a} \frac{d T_{f}}{d x} d x=\left[h_{p f}\left(T_{p}-T_{f}\right)+U_{p v f}\left(T_{p v}-T_{f}\right) b d x\right]
$$

Case B: Glass-to-glass PV module with air channel below the absorber plate For the PV module:

$$
\tau_{g} \alpha_{p v} \beta_{p v} I(t) b d x=\left[U_{t, p v}\left(T_{p v}-T_{a}\right)+h_{p v p}\left(T_{p v}-T_{p}\right)\right] b d x+\tau_{g} \eta_{p v} \beta_{p v} I(t) b d x
$$

For the blackened absorber plate:

$$
\left[\alpha_{p}\left(1-\beta_{p v}\right) \tau_{g}^{2} I(t)+h_{p v p}\left(T_{p v}-T_{p}\right)\right] b d x=h_{p f}\left(T_{p}-T_{f}\right) b d x
$$

For the air channel below the absorber plate:

$$
\dot{m}_{f} C_{f} \frac{d T_{f}}{d x} d x=h_{p f}\left(T_{p}-T_{f}\right) b d x
$$

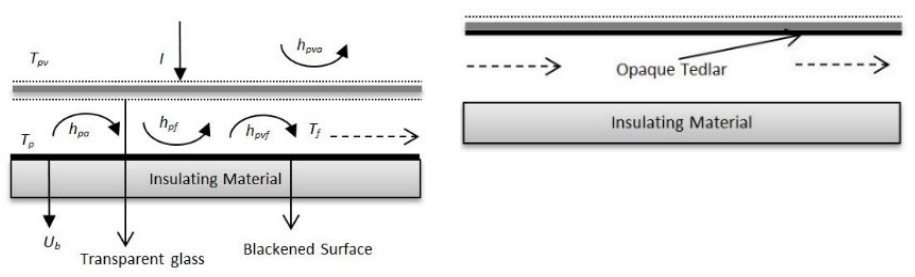

\begin{tabular}{|c|c|c|c|c|c|c|c|}
\hline \multirow[t]{2}{*}{ Year } & \multirow[t]{2}{*}{ Author(s) } & \multirow[t]{2}{*}{ Study } & \multirow{2}{*}{$\begin{array}{l}\text { Performance } \\
\text { Analyses }\end{array}$} & \multicolumn{3}{|c|}{ Energy Efficiencies (\%) } & \multirow{2}{*}{$\begin{array}{l}\text { PVT Exergy } \\
\text { Efficiency } \\
(\%)\end{array}$} \\
\hline & & & & Thermal & PV & Overall & \\
\hline 2007 & Alfegi et al. [40] & Experimental & Energy analysis & $15.2-26.4$ & $11.4-12.7$ & $26.6-39.13$ & NA \\
\hline 2008 & Alfegi et al. [41] & Experimental & Energy analysis & $17-26.43$ & $10.5-12.09$ & $27.5-40.4$ & NA \\
\hline 2009 & Joshi et al. [43] & Experimental & Energy analysis & $26.4-30.5$ & $9.5-11$ & $41.6-47.4$ & NA \\
\hline 2009 & Alfegi et al. [44] & Experimental & Energy analysis & NA & NA & $49.1-62.8$ & NA \\
\hline 2009 & $\begin{array}{l}\text { Dubey et al. } \\
{[45]}\end{array}$ & $\begin{array}{l}\text { Experimental and } \\
\text { theoretical }\end{array}$ & Energy analysis & NA & NA & $9.75-10.41$ & NA \\
\hline 2010 & $\begin{array}{l}\text { Agrawal and } \\
\text { Tiwari [47] }\end{array}$ & $\begin{array}{l}\text { Experimental and } \\
\text { theoretical }\end{array}$ & $\begin{array}{l}\text { Energy-exergy } \\
\text { analysis }\end{array}$ & NA & NA & 53.7 & NA \\
\hline 2010 & $\begin{array}{l}\text { Agrawal and } \\
\text { Tiwari [48] }\end{array}$ & $\begin{array}{l}\text { Experimental and } \\
\text { theoretical }\end{array}$ & $\begin{array}{l}\text { Energy-economic } \\
\text { analysis }\end{array}$ & 33.54 & 7.13 & NA & NA \\
\hline 2010 & $\begin{array}{l}\text { Sarhaddi et al. } \\
{[14]}\end{array}$ & $\begin{array}{l}\text { Experimental and } \\
\text { theoretical }\end{array}$ & Energy analysis & 17.18 & 10 & 45 & NA \\
\hline 2010 & $\begin{array}{l}\text { Sarhaddi et al. } \\
{[15]}\end{array}$ & $\begin{array}{l}\text { Experimental and } \\
\text { theoretical }\end{array}$ & $\begin{array}{l}\text { Energy-exergy } \\
\text { analysis }\end{array}$ & 17.18 & 10 & 45 & 10.75 \\
\hline 2010 & $\begin{array}{l}\text { Shahsavar and } \\
\text { Ameri [49] }\end{array}$ & $\begin{array}{l}\text { Experimental and } \\
\text { theoretical }\end{array}$ & Energy analysis & 60 & 9.5 & 72 & NA \\
\hline 2011 & $\begin{array}{l}\text { Agrawal and } \\
\text { Tiwari [50] }\end{array}$ & Theoretical & $\begin{array}{l}\text { Energy-exergy } \\
\text { analysis }\end{array}$ & 70.62 & NA & NA & NA \\
\hline 2012 & $\begin{array}{l}\text { Amori and Al- } \\
\text { Najjar [51] }\end{array}$ & Theoretical & Energy analysis & $19.4-22.8$ & $9-12.3$ & $47.8-53.6$ & NA \\
\hline 2012 & $\begin{array}{l}\text { Agrawal et al. } \\
\text { 52] }\end{array}$ & $\begin{array}{l}\text { Experimental and } \\
\text { theoretical }\end{array}$ & $\begin{array}{l}\text { Energy-exergy } \\
\text { analysis }\end{array}$ & 35.7 & 12.4 & NA & NA \\
\hline 2013 & $\begin{array}{l}\text { Agrawal and } \\
\text { Tiwari [53] }\end{array}$ & Experimental & $\begin{array}{l}\text { Energy-exergy- } \\
\text { environmental } \\
\text { analysis }\end{array}$ & 32 & NA & NA & NA \\
\hline
\end{tabular}

Figure 7. Design and heat transfer coefficients of the system

\section{PERFORMANCE OF BIPVT AIR COLLECTOR}

Table 1 shows the comparation of Performance of air-based PVT systems.

Table 1. Performance of air-based PVT systems 
Table 1. Performance of air-based PVT systems (continued)

\begin{tabular}{|c|c|c|c|c|c|c|c|c|}
\hline 2014 & $\begin{array}{l}\text { Yang and } \\
\text { Athienitis [24] }\end{array}$ & $\begin{array}{l}\text { Experimental } \\
\text { theoretical }\end{array}$ & and & Energy analysis & 27.1 & 10 & NA & NA \\
\hline 2014 & Kim et al. [54] & Experimental & & Energy analysis & 22 & 15 & NA & NA \\
\hline 2015 & Li et al. [56] & $\begin{array}{l}\text { Experimental } \\
\text { theoretical }\end{array}$ & and & Energy analysis & 50 & $11.9-12.4$ & 77.7 & NA \\
\hline 2015 & Good et al. [57] & Experimental & & Energy analysis & 71.5 & 17.4 & NA & NA \\
\hline 2015 & Ahn et al. [58] & Experimental & & Energy analysis & 23 & 15 & 38 & NA \\
\hline 2015 & $\begin{array}{l}\text { Jahromi et al. } \\
{[59]}\end{array}$ & Theoretical & & $\begin{array}{l}\text { Energy-exergy- } \\
\text { economic analysis }\end{array}$ & $51.6-52$ & $7.5-8.7$ & NA & $9.6-9.7$ \\
\hline 2015 & $\begin{array}{l}\text { Rajoria et al. } \\
{[61]}\end{array}$ & Theoretical & & $\begin{array}{l}\text { Energy-exergy- } \\
\text { enviro-economic } \\
\text { analysis }\end{array}$ & $12.1-28.1$ & $3.1-9.1$ & NA & NA \\
\hline 2016 & $\begin{array}{l}\text { Gholampour } \\
\text { and Ameri [62] }\end{array}$ & Experimental & & $\begin{array}{l}\text { Energy-exergy } \\
\text { analysis }\end{array}$ & 55 & NA & 69.91 & 8.66 \\
\hline 2016 & $\begin{array}{l}\text { Hazami et al. } \\
{[65]}\end{array}$ & $\begin{array}{l}\text { Experimental } \\
\text { theoretical }\end{array}$ & and & $\begin{array}{l}\text { Energy-exergy } \\
\text { analysis }\end{array}$ & 50 & 15 & NA & 14.8 \\
\hline 2017 & Salem et al. [67] & Experimental & & $\begin{array}{l}\text { Energy-exergy } \\
\text { analysis }\end{array}$ & $31.6-57.9$ & $17.7-38.4$ & $59.3-92$ & $11.1-13.5$ \\
\hline 2018 & $\begin{array}{l}\text { Fudholi et al. } \\
{[10]}\end{array}$ & $\begin{array}{l}\text { Experimental } \\
\text { theoretical }\end{array}$ & and & $\begin{array}{l}\text { Energy-exergy } \\
\text { analysis }\end{array}$ & $21.3-82.9$ & $9.87-11.34$ & $31.21-94.24$ & $12.66-12.91$ \\
\hline
\end{tabular}

\section{CONCLUSIONS}

PVT systems combine solar energy and PV collectors, which simultaneously produce heat and electrical energy. The efficiency and energy products from the combination of PV panels and collectors are higher than that of a separated system. Researchers and companies have proposed various designs to improve the overall efficiency of PVT systems. However, the lack of information on the commercial viability and long-term performance of a PVT system decreases its acceptance by the market.

Researchers have developed mathematical models to evaluate the performance of PVT systems with different collector designs. Energy balance is the basic concept in developing the mathematical models at a steady state. The performance of PVT systems is influenced by mass flow rates, collector geometry and other parameters. Model confirmation has been conducted to examine the behaviour of an actual system. To confirm the mathematical model, researchers have assessed either experimental or analytical results. Theoretical and experimental results have been generally consistent when the correct mathematical model is employed. Various approaches are limited because the precision of several key parameters is low and mistakes often occur in obtaining experimental results due to carelessness.

\section{ACKNOWLEDGEMENTS}

We gratefully acknowledge the funding from USAID through the SHERA program-Centre for Development of Sustainable Region (CDSR). In year 2017-2021 CDSR is led by Center for Energy Studies-UGM

\section{REFERENCES}

[1] A. Fudholi, et al., "Energy and exergy analyses of photovoltaic thermal collector with $\nabla$-groove," Solar Energy, vol. 159, pp. 742-50, 2018.

[2] A. Fudholi, et al., "Review of solar drying systems with air-based solar collectors in Malaysia," Renewable and Sustainable Energy Review, vol. 51, pp. 1191-1204, 2015.

[3] A. Fudholi, et al., "Techno-economic of solar drying systems with water based solar collectors in Malaysia: A review," Renewable and Sustainable Energy Review, vol. 51, pp. 809-820, 2015.

[4] A. Fudholi, et al., "Performances and improvement potential of solar drying system for palm oil fronds," Renewable Energy, vol. 78, pp. 561-65, 2015.

[5] A. Fudholi, et al., "Energy and exergy analyses of solar drying system for red seaweed," Energy and Buildings, vol. 68 , pp. 121-29, 2014.

[6] A. Fudholi, et al., "Performance analysis of solar drying system for red chili," Solar Energy, vol. 99, pp. 47-54, 2014.

Int J Pow Elec \& Dri Syst, Vol. 11, No. 2, June 2020 : 1002 - 1010 
[7] A. Fudholi, et al., "Performance analysis of photovoltaic thermal (PVT) water collectors," Energy Conversion and Management, vol. 78, pp. 641-651, 2014.

[8] A. Fudholi, et al., "Collector efficiency of the double-pass solar air collectors with fins," Proceedings of the 9th WSEAS International Conference on System Science and Simulation in Engineering (ICOSSSE'10), pp. 42834, 2010.

[9] A. Fudholi, et al., "Experimental study of the double-pass solar air collector with staggered fins," Proceedings of the 9th WSEAS International Conference on System Science and Simulation in Engineering (ICOSSSE'10), pp. 410$14,2010$.

[10] A. Fudholi, et al., "Design and testing of solar dryer for drying kinetics of seaweed in Malaysia," in Proc. of the 5th Int. Conf. on Energy and Development- Environment-Biomedicine (EDEP'11), pp. 119-124, 2011.

[11] A. Ibrahim et al., "Efficiencies and improvement potential of building integrated photovoltaic thermal (BIPVT) system," Energy Conversion and Management, vol. 77, pp. 527-34, 2014.

[12] A. Fudholi, et al., "Energy analysis and improvement potential of finned double-pass solar collector," Energy Conversion and Management, vol. 75, pp. 234-40, 2013.

[13] A. Fudholi, et al., "Performance and cost benefits analysis of double-pass solar collector with and without fins," Energy Conversion and Management, vol. 76, pp. 8-19, 2013.

[14] Shyam and G.N. Tiwari, "Analysis of series connected photovoltaic thermal air collectors partially covered by semitransparent photovoltaic module", Solar Energy, vol. 137, pp. 137:452-462, 2016.

[15] C.S. Rajoria, et al., "A novel investigation of building integrated photovoltaic thermal (BiPVT) system: A comparative study," Solar Energy, vol. 131, pp. 107-118, 2016.

[16] C.S. Rajoria, et al.,"A newer approach on cash flow diagram to investigate the effect of energy payback time and earned carbon credits on life cycle cost of different photovoltaic thermal array systems," Solar Energy, vol. 124, pp. 254-267, 2016.

[17] S. Agrawal and G.N. Tiwari, "Performance analysis in terms of carbon credit earned on annualized uniform cost of glazed hybrid photovoltaic thermal air collector," Solar Energy, vol. 115, pp. 329-340, 2015.

[18] F. Sarhaddi, et al., "An improved thermal and electrical model for a solar photovoltaic thermal (PV/T) air collector," Applied Energy, vol. 87, pp. 2328-2339, 2010.

[19] F. Sarhaddi, et al., "Exergetic performance assessment of a solar photovoltaic thermal (PV/T) air collector," Energy and Buildings, vol. 42, pp. 2184-2199, 2010.

[20] A. Shahsavar, et al., "Energy saving in buildings by using the exhaust and ventilation air for cooling of photovoltaic panels," Energy and Buildings, vol. 43(9), pp. 2219-2226, 2011.

[21] M.I. Sohel, et al., "A dynamic model for air-based photovoltaic thermal systems working under real operating conditions," Applied Energy, vol. 132, pp. 216-225, 2014.

[22] K. Vats and G.N. Tiwari. "Energy and exergy analysis of a building integrated semitransparent photovoltaic thermal (BISPVT) system," Applied Energy, vol. 96, pp. 409-416, 2012.

[23] T. Yang and A. K. Athienitis. "Experimental investigation of a two-inlet air-based building integrated photovoltaic/thermal (BIPV/T) system," Applied Energy, vol. 159, pp. 70-79, 2015.

[24] N. Aste, et al., "Design, development and performance monitoring of a photovoltaic-thermal (PVT) air collector," Renewable Energy, vol. 33(5), pp. 914-927, 2008.

[25] S. Dubey, et al., "Energy and exergy analysis of PV/T air collectors connected in series," Energy and Buildings, vol. 41(8), pp. 863-870, 2009.

[26] S. C. Solanki, et al., "Indoor simulation and testing of photovoltaic thermal (PV/T) air collectors," Applied Energy, vol. 86(11), pp. 2421-2428, 2009.

[27] A.S. Joshi, et al., "Performance evaluation of a hybrid photovoltaic thermal (PV/T) (glass-to-glass) system," International Journal of Thermal Sciences, vol. 48, pp. 154-164, 2009

\section{BIOGRAPHIES OF AUTHORS}

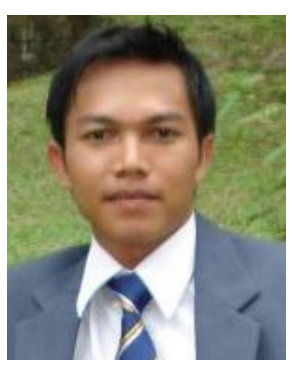

Ahmad Fudholi, Ph.D, M.Sc obtained his S.Si (2002) in physics. He was born in 1980 in Pekanbaru, Indonesia. He served as was the Head of the Physics Department at Rab University Pekanbaru, Riau, Indonesia, for four years (2004-2008). A. Fudholi started his master course in Energy Technology (2005-2007) at Universiti Kebangsaan Malaysia (UKM). After obtaining his Master's, he became a research assistant at UKM until. After his Ph. D (2012) in renewable energy, he became postdoctoral in the Solar Energy Research Institute (SERI) UKM until 2013. He joined the SERI as a lecturer in 2014. He received more than USD 400,000 worth of research grant (16 grant/project) in 2014-2018. He supervised and completed more than $30 \mathrm{M}$. Sc projects. To date, he has managed to supervise nine Ph. D (seven as main supervisors and two as co-supervisor), one Master's student by research mode and one Master's student by coursework mode. He was also an examiner (five $\mathrm{Ph}$. D and one $\mathrm{M}$. Sc). His current research focus is renewable energy, particularly solar energy technology, micropower systems, solar drying systems and advanced solar thermal systems (solar-assisted drying, solar heat pumps, PVT systems). He has published more than 120 peer-reviewed papers, of which 37 papers are in the ISI index (more $25 \mathrm{Q} 1$, impact factor more than 4) and more than 80 papers are in the Scopus index. He has published more than 80 papers in international conferences. He has a total citation of 1225 and a h-index of 17 in Scopus (Author ID: 57195432490). He has a total citation of 1684 
and a h-index of 21 in Google Scholar. He has been appointed as reviewer of high-impact (Q1) journals. He has also been appointed as editor of journals. He has received several international awards. He has also been invited as speaker in the Workshop of Scientific Journal Writing; Writing Scientific Papers Steps Towards Successful Publish in High Impact (Q1) Journals. He owns one patent and two copyrights.

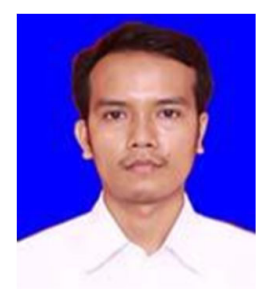

Muhammad Zohri, M.Sc REN obtained his S.Si (2009) in physics. Originally from Lombok, Indonesia, he graduated with M.Sc (2017) in Renewable Energi from Solar Energy Research Institute (SERI) UKM, Malaysia. He was appointed a Graduate Research Assistant (GRA) under Dr. Ahmad Fudholi. His M.Sc thesis was under the supervision of Dr. Ahmad Fudholi. His M.Sc dissertation was on the Performances of Photovoltaic-Thermal (PVT) with and without VCollectors. He has published 10 Papers, which 7 Paper in Scopus Index with a h-index of 3. His current research focus is on solar energy technology. Currently, he is a $\mathrm{PhD}$ candidate under the main supervision of Dr. Ahmad Fudholi at the SERI in Universiti Kebangsaan Malaysia.

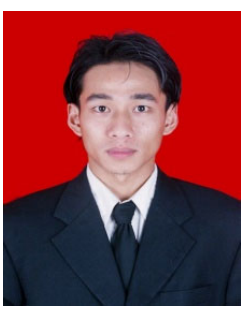

Ivan Taslim, S.Si, M.T from South Sulawesi, Indonesia. He graduated with the M.T in Geology Engineering from University of Hasanuddin in 2014. In 2015, he joined as lecturer at the Department of Geography, Faculty of Science and Technology, University of Muhammadiyah Gorontalo. His main areas of research interest are Management Risk Disaster, Geospatial Data Science and Climate Change with no limited to Renewable Energy. He is currently one of the researchers from USAID SHERA who focuses on developing and using renewable energy in Indonesia. Currently, he is entrusted to work with the Gorontalo Regional Government as a staff in the field of Climate Change and Disaster Mitigation.

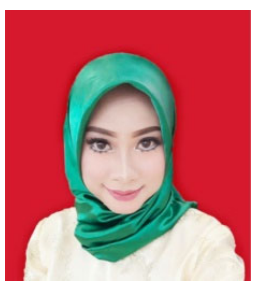

Merita Ayu Indrianti, S.P., M.P from Banjarmasin South Borneo, Indonesia. She graduated in Agriculture from University of Hasanuddin in 2016. She has working as a lecturer at the Department of Agriculture University of Muhammadiyah Gorontalo since 2014. Her main areas of research interest are Socio-Economic in Agriculture, Biomass and Biogas energy and Integrated Farming System for Food Security. In her career, she had served as secretary of the Agricultural Study Center (2015) and secretary of the Agribusiness study program (2016) in Department of Agriculture.

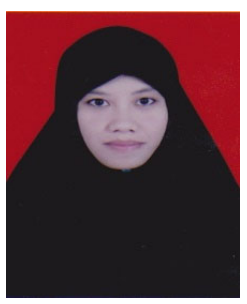

Intan Noviantari Manyoe, S.Si, M.T from Gorontalo, Indonesia. She was born in 1982, and graduate from University of Hasanuddin with a degree in Geophysics and have a masters in Geology Engineering in 2014. She is working as a lecture at the Department of Geology also Head of Geology Engineering Laboratory at University State of Gorontalo. Her main areas of research interest are Geophysics, Tectonic, Volcano and Geothermal. 